\title{
Precommercial thinning of overtopping aspen to release coniferous regeneration in a boreal mixedwood stand
}

\author{
by Marcel Prévost ${ }^{1}$ " and Lise Charette ${ }^{1}$
}

\begin{abstract}
We used precommercial thinning (PCT) to accelerate natural succession in an 8-year-old, even-aged stratified mixture, in which trembling aspen (Populus tremuloides) overtopped a dense understory of balsam fir (Abies balsamea) and spruce (Picea mariana, P. glauca). In addition to an unthinned control, we applied three residual aspen spacings $(2.5,3.0$ and $3.5 \mathrm{~m})$ while retaining all understory conifers, and a $3.0-\mathrm{m}$ spacing retaining only small conifers $(<1 / 3$ of the aspen crop tree height). PCT improved survival of spruce, increased diameter growth of aspen by $90 \%$ and doubled diameter and height growth of conifers, without differences among spacings or between levels of conifer retention after 10 years. The level of conifer retention did not affect aspen growth response, but appeared to influence the occurrence of browsing on aspen and balsam fir. Retaining only small conifers decreased regeneration density of balsam fir in favour of abundant vegetative reproduction of red maple (Acer rubrum) and beaked hazelnut (Corylus cornuta). Live crown characteristics and stand structure indicate that thinning caused a shift from overtopping of aspen to an intimate mixture of species sharing the growing space. This study confirms PCT as a means of accelerating natural succession in a boreal mixedwood stand, thereby securing the coniferous component at the early stage of development.
\end{abstract}

Key words: ecosystem-based forest management; hardwood conversion; stratified species mixture; precommercial thinning; live crown characteristics.

\section{RÉSUMÉ}

Nous avons utilisé l'éclaircie précommerciale (EPC) afin d'accélérer la succession naturelle dans un mélange équien stratifié de 8 ans, dans lequel le peuplier faux-tremble (Populus tremuloides) surplombait une dense régénération de sapin baumier (Abies balsamea) et d'épinette (Picea mariana, P. glauca). En plus d'un témoin non éclairci, nous avons appliqué trois espacements résiduels entre les trembles $(2,5,3,0$ et $3,5 \mathrm{~m})$ en conservant tous les conifères du sous-étage, et un espacement de 3,0 $\mathrm{m}$ en conservant seulement les petits conifères $(<1 / 3$ de la hauteur du tremble éclairci). L'EPC a amélioré la survie de lépinette, augmenté la croissance en diamètre du tremble de $90 \%$ et doublé la croissance en diamètre et en hauteur des conifères, sans différences entre les espacements ou entre les niveaux de rétention des conifères après 10 ans. Le niveau de rétention des conifères n’a pas affecté la réponse de croissance du tremble, mais a semblé influencer la fréquence du broutement sur le tremble et le sapin. La rétention des petits conifères seulement a diminué la densité de la régénération de sapin au profit d'une abondante reproduction végétative dérable rouge (Acer rubrum) et de noisetier à long bec (Corylus cornuta). Les caractéristiques des cimes vivantes et la structure du peuplement indiquent que léclaircie a amené le peuplement à passer d'une dominance du tremble à un mélange intime d'espèces se partageant l'espace de croissance. Cette étude confirme que l'EPC est un moyen d’accélérer la succession naturelle dans un peuplement mixte boréal, en assurant le maintien de la composante résineuse dès le stade initial.

Mots-clés: aménagement écosystémique; enfeuillement; mélange stratifié d’espèces; éclaircie précommerciale; caractéristiques des cimes vivantes.

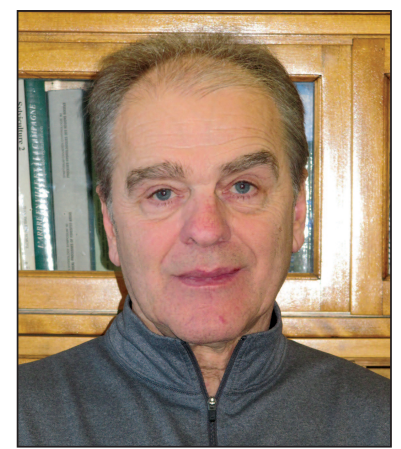

Marcel Prévost

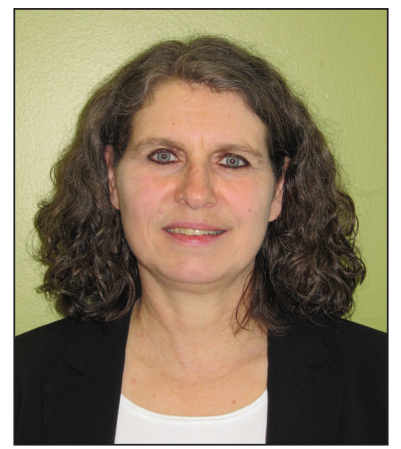

Lise Charette

\footnotetext{
${ }^{1}$ Ministère des Forêts, de la Faune et des Parcs du Québec, Direction de la recherche forestière, 2700, rue Einstein, Québec, QC G1P 3W8, Canada ${ }^{\star}$ Corresponding author E-mail address: marcel.prevost@mffp.gouv.qc.ca
} 


\section{Introduction}

Precommercial thinning (PCT) is used in young forest stands to redistribute growing space to a reduced number of residual trees (Smith et al. 1997). These crop trees benefit from increased light (Pothier and Margolis 1991, Prévost and Gauthier 2012), water and nutrients (Thibodeau et al. 2000), while the felled trees are left to decay on the ground and contribute to nutrient cycling (e.g., Sterba 1988). Moreover, PCT may have beneficial effects on soil fertility through increases in soil temperature, decomposition rates, and nitrogen pools over the short-term (Thibodeau et al. 2000). Several studies have shown that PCT is effective in reducing stand density, increasing the growth rate of selected trees, adjusting species composition, and improving overall stand quality from the earliest stages of development (e.g., Brissette et al. 1999).

Historically, PCT was practiced to avoid stagnation in dense pure stands originating from natural or artificial seeding (Smith et al. 1997). Several PCT experiments were therefore conducted in pure or nearly pure (ca. $\geq 75 \%$ basal area, BA) stands (e.g., Karsh et al. 1994), in mixtures with conifers (Brissette et al. 1999, Weiskittel et al. 2009) or hardwoods (Voorhis 1990, Nicholson et al. 2010). Generally, both conifer and hardwood species benefit from increased resource availability with gains in diameter at breast height (DBH) that increase with spacing. For the two species groups however, high branch retention on the lower bole (Weiskittel et al. 2009, Nicholson et al. 2010), and low wood density and lumber strength (Zhang et al. 2006) may result from wide spacing. Consequently, the trade-off between diameter gain and subsequent quality of the wood products is an important consideration when choosing an intensity of PCT (Nicholson et al. 2010).

In the Canadian boreal forest, PCT increased DBH growth of balsam fir (Abies balsamea (L.) Mill.) (Pothier 2002, Pitt and Lanteigne 2008, Zhang et al. 2009), red spruce (Picea rubens Sarg.) (Pitt and Lanteigne 2008), and to a lesser extent jack pine (Pinus banksiana Lamb.) (Zhang et al. 2006). The effects observed on black spruce (Picea mariana (Mill.) B.S.P.) were weak or even negligible in some experiments (e.g., McClain et al. 1994, Fleming et al. 2005), but good growth responses have been obtained on productive sites (Karsh et al. 1994, Newton and Weetman 1994). Experiments conducted in the eastern United States and Canada also have reported significant DBH growth increases to PCT for northern hardwoods including paper birch (Betula papyrifera Marsh.) and red maple (Acer rubrum L.) (Voorhis 1990, Nicholson et al. 2010, Leak and Yamasaki 2012, Swift et al. 2017). For trembling aspen (Populus tremuloides Michx.), the literature on PCT is rather equivocal, with either increases in individual tree DBH (e.g., Rice et al. 2001) or no response (e.g., Penner et al. 2001). As a result, the implementation of PCT in aspen stands is still under debate, given that this shade-intolerant species readily regenerates through root suckering and selfthins (Perala 1990).

In the Canadian boreal mixedwood forest, a dense aspen cover of sucker origin often overtops an understory of balsam fir and spruce (Picea glauca (Moench) Voss, P. mariana), which survived as advance growth or became established post-harvest. The widespread presence of aspen on the land- scape and the increasing protection of conifer advance growth in current management practices (Groot et al. 2005) should favour development of this type of even-aged stratified mixture along successional pathways (Smith et al. 1997). In such stands, PCT has traditionally prioritized conifers over early successional broadleaved species (e.g., Pitt and Bell 2005), whereas growing species in mixtures has received little attention so far (e.g., Bokalo et al. 2007, Kabzems et al. 2016). For example, Rice et al. (2001) suggested that PCT be considered as a means of increasing aspen diameter and allowing conifer ingress to be established within the resultant openings. A more recent PCT experiment (Prévost and Gauthier 2012) tested different spacings of aspen, while preserving sparse balsam fir regeneration. This experiment yielded promising results, as PCT increased growth of both the residual aspen and the understory fir. This response prompted the initiation of the present study in a typical stratified mixture that contained a denser understory of both fir and spruce. This allowed us to assess post-thinning development of an intimate species mixture.

In addition to maintaining the conifer fraction in order to prevent hardwood conversion (Prévost and Gauthier 2012), favouring species mixtures may present some advantages over pure stands. For instance, spatial complementarity among tree crowns may allow better exploitation of light and other resources (Williams et al. 2017). In the case of aspen and white spruce in the boreal mixedwood forest, Man and Lieffers (1999) concluded that these species may avoid competition and produce greater yields in mixture because of the physical separation of their canopies, and their differential shade-tolerance, phenology and soil resource utilization. Aspen could even positively affect spruce growth by enhancing litter decomposition and nutrient cycling (Van Cleve et al. 1983). Among other possible advantages of species mixtures are increased resilience against insect and disease outbreaks (Su et al. 1996) and a greater diversity of forest products (MacDonald 1995).

This study presents the results of a PCT experiment that was aimed at accelerating natural succession in a stratified mixture, in which aspen overtopped a dense understory of fir and spruce. The principal objective was to define a spacing that would be beneficial to both aspen crop trees and released understory conifers. A secondary objective was to assess two different levels of advance growth protection: (1) retaining conifers of all heights; and, (2) retaining only small conifers, i.e., $<1 / 3$ the height of the aspen crop tree within a $2-m$ intertree radius, which is the operational standard in Quebec. We present the 10-year effects of PCT on DBH, height, BA and crown characteristics of aspen crop trees and understory conifers. We hypothesized that (i) aspen DBH growth would be proportional to spacing (Rice et al. 2001), (ii) conifers will be released and their DBH and height growth would be proportional to aspen spacing, (iii) the level of conifer advance growth retention would not affect growth of aspen in the overstory, (iv) PCT in overstory aspen would be more beneficial to balsam fir than to spruce (Prévost et al. 2016), and (v) PCT would affect natural ingress of fir and spruce after treatment (Prévost and Gauthier 2012). 


\section{Material and Methods \\ Site description}

The study site was located in the balsam fir - yellow birch bioclimatic domain (region 4d), in the High Hills of Charlevoix and Saguenay (Saucier et al. 2009), about $160 \mathrm{~km}$ northeast of Québec City, Quebec, Canada ( $47^{\circ} 55^{\prime}$ N, $70^{\circ} 04^{\prime}$ W). Mean daily maximum temperature (1981-2010, Petit-Saguenay station) is recorded in July $\left(23.5^{\circ} \mathrm{C}\right)$ and minimum temperature is recorded in January $\left(-18.8^{\circ} \mathrm{C}\right)$, with a mean annual temperature of $3.1^{\circ} \mathrm{C}$. The region annually receives $1041 \mathrm{~mm}$ of precipitation on average, with $31 \%$ falling as snow (MDDELCC 2016).

The previous stand was clearcut in 1997 before the growing season (based on annual rings), with protection of the conifer advance regeneration, and regenerated naturally. For all saplings $\geq 1 \mathrm{~cm} \mathrm{DBH}$, stand density was 31400 stems/ha, with $78 \%$ commercial species including aspen (44\%), red maple (18\%), balsam fir (9\%), paper birch (6\%) and spruce ( 2/3 P. mariana and $\sim 1 / 3$ P. glauca) (1\%). The stand was at an early stage of the even-aged stratified mixture as described by Smith et al. (1997), in which aspen was 4-6 $\mathrm{m}$ and conifers were 2-3 $\mathrm{m}$ in height. Noncommercial species (22\%) included mountain maple (Acer spicatum Lamb.) (9\%), beaked hazelnut (Corylus cornuta Marsh.) (6\%), striped maple (Acer pensylvanicum L.) (3\%) and other species (willow (Salix spp.) and pin cherry (Prunus pensylvanica L. f.), 4\%). The soil was a sandy loam with a mesic drainage on a less than $10 \%$ northwest-facing slope.

\section{Experimental design}

The experiment consisted of four complete randomized blocks, each one containing five treatments: an unthinned control $(\mathrm{CON})$; three targeted residual aspen spacings $(2.5$, 3.0 and $3.5 \mathrm{~m}$ ) retaining coniferous regeneration of all sizes (referred to as $2.5 \mathrm{~A}, 3.0 \mathrm{~A}$ and $3.5 \mathrm{~A}$ ); and a $3.0-\mathrm{m}$ spacing retaining only small coniferous regeneration (3.0S), i.e., felling all advance growth $\geq 1 / 3$ of the aspen crop tree height within a 2-m radius. Treatments of each block were contiguous and distributed across the slope, using slope position as blocking factor. Each experimental unit measured $50 \mathrm{~m} \times 50 \mathrm{~m}$ $(0.25 \mathrm{ha})$ and contained a $20 \mathrm{~m} \times 20 \mathrm{~m}$ centre plot $\left(400 \mathrm{~m}^{2}\right)$ from which precise measurements were taken. In each $400-\mathrm{m}^{2}$ plot, sixteen $4-\mathrm{m}^{2}$ subplots $(2 \mathrm{~m} \times 2 \mathrm{~m})$ were installed in a systematic grid pattern to measure regeneration.

PCT was carried out in late September 2004 at the end of the $8^{\text {th }}$ growing season after the clearcut. Aspen stems that were retained were marked prior to treatment according to the targeted spacing and their overall quality. These latter criteria included tree height and diameter, and the absence of injury, infection or insect damage. To avoid selection of poor quality stems, spacing was lowered by $1 \mathrm{~m}$ of the targeted spacing (i.e., $1.5 \mathrm{~m}$ instead of $2.5 \mathrm{~m}$ ). All other stems, except for the conifers that were retained, were felled using spacing saws. Cut stems were left to decay on the ground, while preventing their physical contact with crop trees to avoid injuries to the live individuals.

\section{Vegetation monitoring}

In August 2004 and prior to thinning, all saplings ( $\geq 1.3 \mathrm{~m}$ in height) located in each $400-\mathrm{m}^{2}$ plot were tallied by species and
DBH class $(1,2,4,6,8$ and $10 \mathrm{~cm})$. This inventory was used to estimate the initial stem density at stand-level. After thinning, all residual saplings in each plot were tagged in October and November 2004. Species, DBH, total height, crown height and four crown radii $(\mathrm{N}, \mathrm{E}, \mathrm{S}$ and $\mathrm{W})$ were then recorded as year 0 measurements. In the unthinned control, saplings were tagged and measured in the $4-\mathrm{m}^{2}$ subplots only. At post-treatment years 1-5, 7 and 10 (2005-2009, 2011 and 2014), DBH and total height of all tagged stems were measured, whereas crown height and crown radii were measured only at years 5 and 10 . Presence of mechanical injuries, infections or insect damage, together with traces of browsing by moose (Alces alces) or snowshoe hare (Lepus americanus), were recorded across all measurement years. Finally, all commercial species and major noncommercial species were counted by height class $(1-5,6-30,31-60,61-100,101-200$, $201-300$ and $>300 \mathrm{~cm}$ ) in the regeneration subplots at years $1-3,5,7$ and 10 post-thinning.

\section{Statistical analyses}

$\mathrm{DBH}$, height and BA measured at years $0-5,7$ and 10 after PCT, and live crown characteristics measured at years 0,5 and 10 , were analyzed by species for aspen, fir and spruce (pooled white and black spruces). Regeneration density measured at post-thinning years $1-3,5,7$ and 10, was also analyzed separately by species (aspen, paper birch, red maple, spruce, fir, mountain maple, striped maple, beaked hazelnut and pin cherry). Linear mixed models with repeated measurements were used, with a variance-covariance matrix to take into account the correlation between measurements that were performed on the same experimental units. The choice of this matrix was made using goodness-of-fit and parsimony criteria, while taking into account the unequal time intervals and maintaining consistency among the set of analyses. PCT treatments, measurement years and their interaction were introduced into the model as fixed-effect factors, whereas blocks and experimental units were considered as random effects. For DBH, height, BA, crown characteristics and regeneration density of each species, the pre-thinning (2004) density of saplings $\geq 1.3 \mathrm{~m}$ in height was tested as a covariate. It was included in the model when significant, in which case the equal slopes hypothesis was tested (non-significant interaction of covariate and fixed effects when the covariate is in the model). Data for decennial mortality and occurrence of browsing were analyzed separately for each commercial species and expressed in \% $(100 \times$ number of stems that died or were browsed from years $1-10$ / number of stems at year 0 ).

A priori specific contrasts of treatments were tested as follows: $i$ ) PCT retaining all coniferous regeneration (mean of $2.5 \mathrm{~A}, 3.0 \mathrm{~A}$ and $3.5 \mathrm{~A}$ ) vs. the unthinned control; ii) PCT retaining small coniferous regeneration $(3.0 \mathrm{~S})$ vs. the control; iii) pairwise among the three PCT retaining all coniferous regeneration (2.5A vs. $3.0 \mathrm{~A}, 2.5 \mathrm{~A}$ vs. $3.5 \mathrm{~A}$ and $3.0 \mathrm{~A}$ vs. $3.5 \mathrm{~A})$; and iv) PCT retaining all vs. small coniferous regeneration (3.0A vs. 3.0S). The first two contrasts were tested along with a one-sided alternative in favour of PCT treatments for DBH and height, and in favour of the control for BA. The third contrast was also a one-sided alternative in favour of the wider spacing for DBH and height, and two-sided for BA. The 
fourth contrast was two-sided for all variables. For tree mortality, browsing, live crown characteristics and regeneration density, all tests were two-sided. Orthogonal polynomial decomposition of the time effect (linear, quadratic and cubic) was performed, taking into account the unequal time intervals by using the ORPOL function of the IML SAS procedure (v. 9.4, SAS Institute Inc., Cary, NC). For significant interactions between main factors, contrasts were compared at years 0, 5 and 10 for $\mathrm{DBH}$, height, $\mathrm{BA}$ and crown characteristics, whereas the time effect was decomposed for every PCT treatment. For regeneration density, the same contrasts were compared at years 1, 5 and 10, but time intervals for years 1-2, $2-3,3-5,5-7,7-10,1-5$ and $5-10$ were tested for every treatment, in order to detect pulses in recruitment or mortality. Homogeneity of variances and normality were assessed on scaled residuals using standard graphical methods, together with the Brown and Forsythe's test (homogeneity) and the Shapiro-Wilk's test (normality). When required, data were transformed $(\sqrt{ } \mathrm{x})$ to improve homogeneity of variance, although they are presented in their original form in the Results section. The level of significance was 0.05 for all analyses and tests.

Analyses were performed using the MIXED procedure of SAS for DBH, height, BA, live crown characteristics and regeneration density, and the GLIMMIX procedure for mortality and browsing, using the logit-link function. The Kenward-Roger approximation was used to estimate the denominator degrees of freedom in the ANOVA models. A simulation-based approach was used to assess differences while considering tests multiplicity in all cases where a factor or an interaction was significant. In the case of interactions, the 0.05 error rate was applied within each fixed level of the main factors, as a separate-family approach (Westfall et al. 2011). The approach of Braat et al. (2008) was used to transform all tests to their one-sided form to deal with the simultaneous application of one-sided and two-sided tests. A limitation of this framework is that in the case of two-sided tests, adjusted confidence intervals are used to assess significance rather than the usual adjusted $p$-values.

\section{Results}

Ten-year tree mortality and browsing

After 10 years, tree mortality was related to PCT for trembling aspen $(p<0.001$, not presented) and spruce $(p=0.017)$. Aspen mortality was higher in the unthinned CON (52\%) than in every PCT treatment $(4-7 \%, p \leq 0.004)$. Similarly, spruce mortality was higher in the CON (24\%) than in PCT treatments that retained all conifers $(2.5 \mathrm{~A}, 3.0 \mathrm{~A}$ and $3.5 \mathrm{~A}$ : $3-4 \%, p=0.010)$, and appeared to be higher than in the PCT treatment that retained only small conifers (3.0S: $0 \%$ mortality, therefore excluded from the test). PCT tended to affect browsing on balsam fir $(p=0.060)$ and aspen $(p=0.095)$ by lowering the mean occurrence on fir in treatments $2.5 \mathrm{~A}, 3.0 \mathrm{~A}$ and $3.5 \mathrm{~A}(3 \%$ vs. $11 \%$ in the $\mathrm{CON}, p=0.057)$ and increasing the occurrence on aspen in the treatment $3.0 \mathrm{~S}$ (19\% vs. $3 \%$ in the unthinned CON, $p=0.093$ ).

\section{Growth}

$D B H$, height and $B A$

An interaction of PCT with time $(\mathrm{PCT} \times \mathrm{T})$ was found in $\mathrm{DBH}$ of trembling aspen, balsam fir and spruce (all $p<0.001$, Table 1; Fig. 1). For each species, the DBH was comparable

Table 1. Analysis of variance and probabilities $[P>F$ for trembling aspen, balsam fir and spruce DBH, height and BA measured $0,1,2,3,4,5,7$ and 10 years after PCT and crown characteristics measured 0,5 and 10 years after PCT: unthinned control, 2.5-, 3.0- and 3.5-m aspen spacings protecting all understory conifers and a 3.0-m spacing protecting only small understory conifers $[<1 / 3$ of the retained aspen height].

\begin{tabular}{|c|c|c|c|c|c|c|c|c|c|}
\hline $\begin{array}{l}\text { Source of } \\
\text { variation }\end{array}$ & df & $\mathrm{DBH}$ & Height & BA & df & $\begin{array}{l}\text { Crown } \\
\text { width }\end{array}$ & $\begin{array}{l}\text { Crown } \\
\text { length }\end{array}$ & $\begin{array}{c}\text { Bole } \\
\text { length }\end{array}$ & $\begin{array}{c}\text { Live } \\
\text { crown } \\
\text { ratio }\end{array}$ \\
\hline \multicolumn{10}{|c|}{ Trembling aspen } \\
\hline PCT & 4 & 0.005 & 0.417 & 0.042 & 4 & $<0.001$ & 0.010 & 0.379 & $<0.001$ \\
\hline Time $(\mathrm{T})$ & 7 & $<0.001$ & $<0.001$ & $<0.001$ & 2 & $<0.001$ & $<0.001$ & $<0.001$ & $<0.001$ \\
\hline $\mathrm{PCT} \times \mathrm{T}$ & 28 & $<0.001$ & 0.469 & 0.059 & 8 & 0.004 & $<0.001$ & 0.044 & $<0.001$ \\
\hline Covariate & 1 & $<0.001$ & $<0.001$ & 0.001 & 1 & - & 0.029 & $<0.001$ & - \\
\hline \multicolumn{10}{|l|}{ Balsam fir } \\
\hline PCT & 4 & 0.311 & 0.485 & 0.008 & 4 & 0.001 & 0.391 & 0.126 & 0.409 \\
\hline Time $(\mathrm{T})$ & 7 & $<0.001$ & $<0.001$ & $<0.001$ & 2 & $<0.001$ & $<0.001$ & $<0.001$ & 0.003 \\
\hline $\mathrm{PCT} \times \mathrm{T}$ & 28 & $<0.001$ & $<0.001$ & 0.010 & 8 & 0.560 & $<0.001$ & 0.332 & $<0.001$ \\
\hline Covariate & 1 & - & - & 0.002 & 1 & - & - & - & - \\
\hline \multicolumn{10}{|l|}{ Spruce } \\
\hline PCT & 4 & 0.362 & 0.590 & 0.533 & 4 & 0.182 & 0.284 & 0.169 & 0.538 \\
\hline Time $(\mathrm{T})$ & 7 & $<0.001$ & $<0.001$ & $<0.001$ & 2 & $<0.001$ & $<0.001$ & $<0.001$ & 0.001 \\
\hline $\mathrm{PCT} \times \mathrm{T}$ & 28 & $<0.001$ & $<0.001$ & 0.785 & 8 & 0.040 & $<0.001$ & 0.008 & $<0.001$ \\
\hline Covariate & 1 & - & - & 0.015 & 1 & - & - & - & - \\
\hline
\end{tabular}

Note: The variance-covariance matrix was spatial power for all variables and species, except for crown width of aspen and fir (variance components). $d f=\mathrm{degrees}$ of freedom of the numerator. Denominator degrees of freedom, according to Kenward-Roger: PCT $=6.5$ to $42.0, \mathrm{~T}=12.1$ to 105.0 , PCT $\times \mathrm{T}=18.8$ to 105.0 , Covariate $=3.0$ to 14.1 . Significant $p$-values are presented in boldface type. A dash indicates that the covariate was not significant and was removed from the model. 


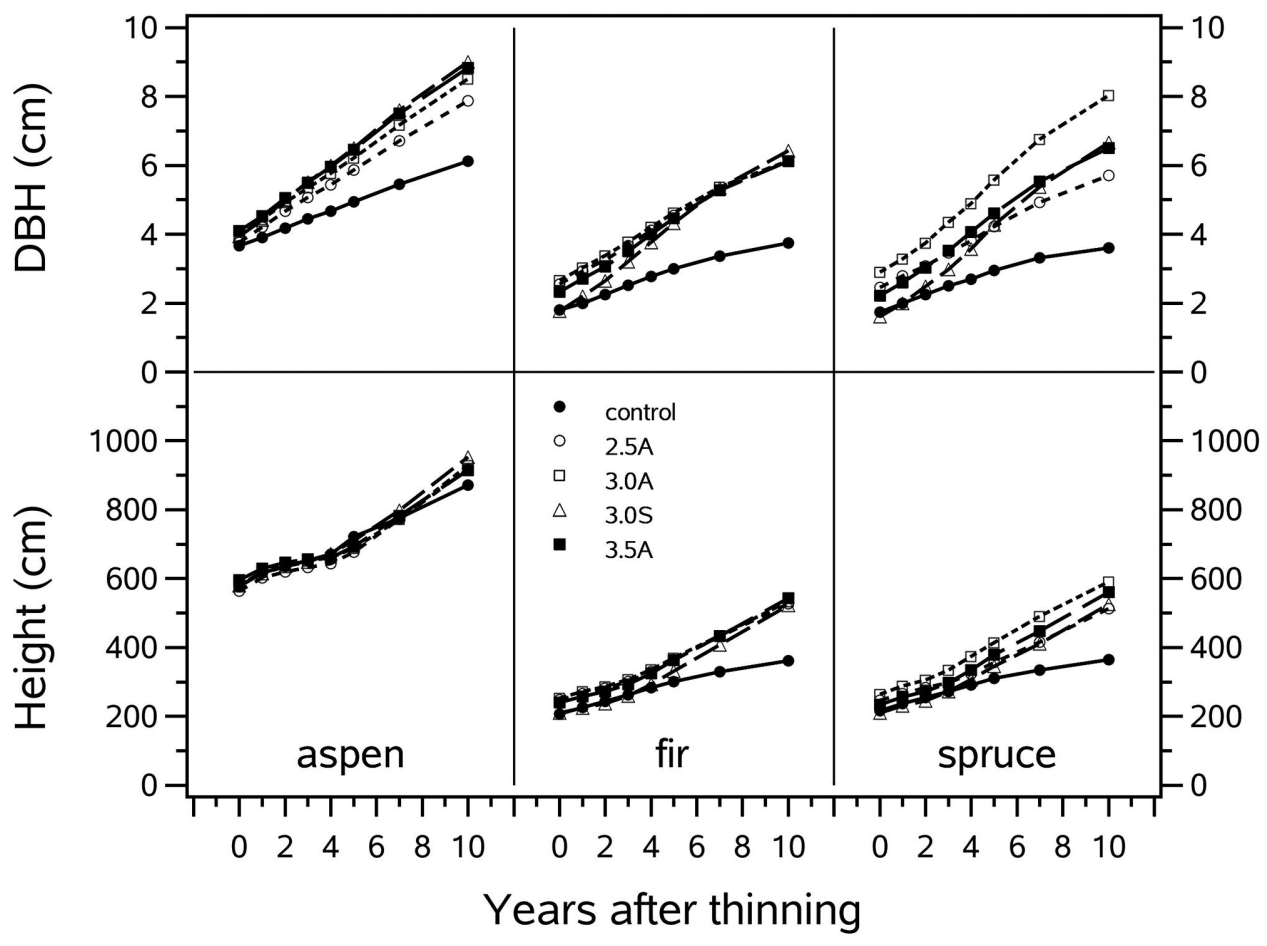

Fig. 1. $\mathrm{DBH}$ and total height related to species and PCT treatment: unthinned control, 2.5-, 3.0- and 3.5-m aspen spacings protecting all understory conifers (respectively 2.5A, 3.0A and 3.5A), and a 3.0-m spacing protecting only small understory conifers (3.0S), at years $0-5,7$ and 10 post-thinning.

among treatments immediately post-thinning (year 0 ). However, the DBH was higher in treatments $2.5 \mathrm{~A}, 3.0 \mathrm{~A}$ and $3.5 \mathrm{~A}$ $(5.9-6.4 \mathrm{~cm})$, and $3.0 \mathrm{~S}(6.5 \mathrm{~cm})$ than in the $\mathrm{CON}(4.9 \mathrm{~cm})$ at years 5 and 10 (respectively 7.9-8.8, 9.0 and $6.1 \mathrm{~cm}$ ) for aspen $(p \leq 0.002$ ), and at year 10 for fir (all 6.1, 6.4 and $3.7 \mathrm{~cm}$, $p \leq 0.016)$ and spruce $(5.7-8.0,6.7$ and $3.6 \mathrm{~cm}, p \leq 0.036)$. The time effect was a linear increase in aspen $\mathrm{DBH}$, with growth rates of $0.41-0.51 \mathrm{~cm} /$ year in PCT treatments and $0.24 \mathrm{~cm} /$ year in the CON. For the two conifers, the decennial $\mathrm{DBH}$ increase was also linear in the CON (both $0.19 \mathrm{~cm} /$ year). In PCT treatments, cubic (sigmoidal) time effects were related to variations in growth rates that resulted in mean increases of $0.34-0.46 \mathrm{~cm} /$ year for fir and $0.32-0.51 \mathrm{~cm} /$ year for spruce.

A significant PCT $\times$ T interaction was found in height of fir and spruce, while only a time effect was found in height of aspen (all $p<0.001$, Table 1; Fig. 1). The height of each conifer was comparable among treatments at years 0 and 5 . Both species were taller in treatments $2.5 \mathrm{~A}, 3.0 \mathrm{~A}$ and $3.5 \mathrm{~A}$ (fir: $527-543 \mathrm{~cm}$, spruce: $513-592 \mathrm{~cm}$ ), and $3.0 \mathrm{~S}$ (respectively 523 and $526 \mathrm{~cm})$ than in the CON (361 and $365 \mathrm{~cm})$ at year 10 ( $p \leq 0.048$ ). Cubic time effects following thinning (all $p<0.001)$ resulted in mean increases of $28-31 \mathrm{~cm} /$ year for fir and $27-33 \mathrm{~cm} /$ year for spruce. For aspen, a quadratic time effect was related to an increasing growth rate over time. PCT did not affect aspen height growth.

An interaction was also found in BA of balsam fir ( $p=0.010$, Table 1 ; data not shown). Balsam fir BA was not statistically different between $3.0 \mathrm{~A}\left(2.8 \mathrm{~m}^{2} / \mathrm{ha}\right)$ and $3.0 \mathrm{~S}(0.6$ $\mathrm{m}^{2} / \mathrm{ha}$ ) at year 0 , but was higher in $3.0 \mathrm{~A}$ than in $3.0 \mathrm{~S}$ at both years 5 (6.2 vs. $2.0 \mathrm{~m}^{2} / \mathrm{ha}$ ) and 10 (10.3 vs. $\left.3.8 \mathrm{~m}^{2} / \mathrm{ha}\right)$, due to the magnitude of their linear increase $(0.75$ vs. $0.31 \mathrm{~m}^{2} /$ ha/year, both $\left.p<0.001\right)$. Single effects of PCT $(p=0.042)$ and time $(p<0.001)$ were found in BA of aspen. As a whole, aspen BA was significantly lower in all PCT treatments compared to the CON. For instance, BA was 1.2-1.9 vs. $10.2 \mathrm{~m}^{2} /$ ha at year $0,2.9-4.5$ vs. $17.2 \mathrm{~m}^{2} /$ ha at year 5 and 5.5-8.1 vs. $23.7 \mathrm{~m}^{2} / \mathrm{ha}$ at year 10 , with a linear increase $(p<0.001)$ of $0.43-0.62 \mathrm{~m}^{2} / \mathrm{ha} /$ year in PCT treatments and $1.35 \mathrm{~m}^{2} /$ ha/year in the CON. Only a time effect was found in $\mathrm{BA}$ of spruce, with an overall increase of $0.11 \mathrm{~m}^{2} / \mathrm{ha} /$ year.

\section{Live crown characteristics}

PCT and time interacted in the responses for crown length and live crown ratio of the three species, and for crown width and bole length of aspen and spruce ( $p \leq 0.044$, Table 1; Figs. 2 and 3). All crown characteristics of the three species were comparable among treatments at year 0 and the four PCT treatments showed enhanced crown development over the 10 -year period. The PCT effect on crown width, crown length and live crown ratio was detected at years 5 and 10 for aspen $(p \leq 0.009)$, but only at year 10 for conifers $(p \leq 0.049)$. For instance, at year 10, crown length in PCT treatments and the CON were $492-560$ vs. $315 \mathrm{~cm}$ for aspen, 393-423 vs. $240 \mathrm{~cm}$ for fir, and 391-469 vs. $246 \mathrm{~cm}$ for spruce. At this time, bole length of spruce was lower in the $3.0 \mathrm{~S}(78 \mathrm{~cm})$ than in the 


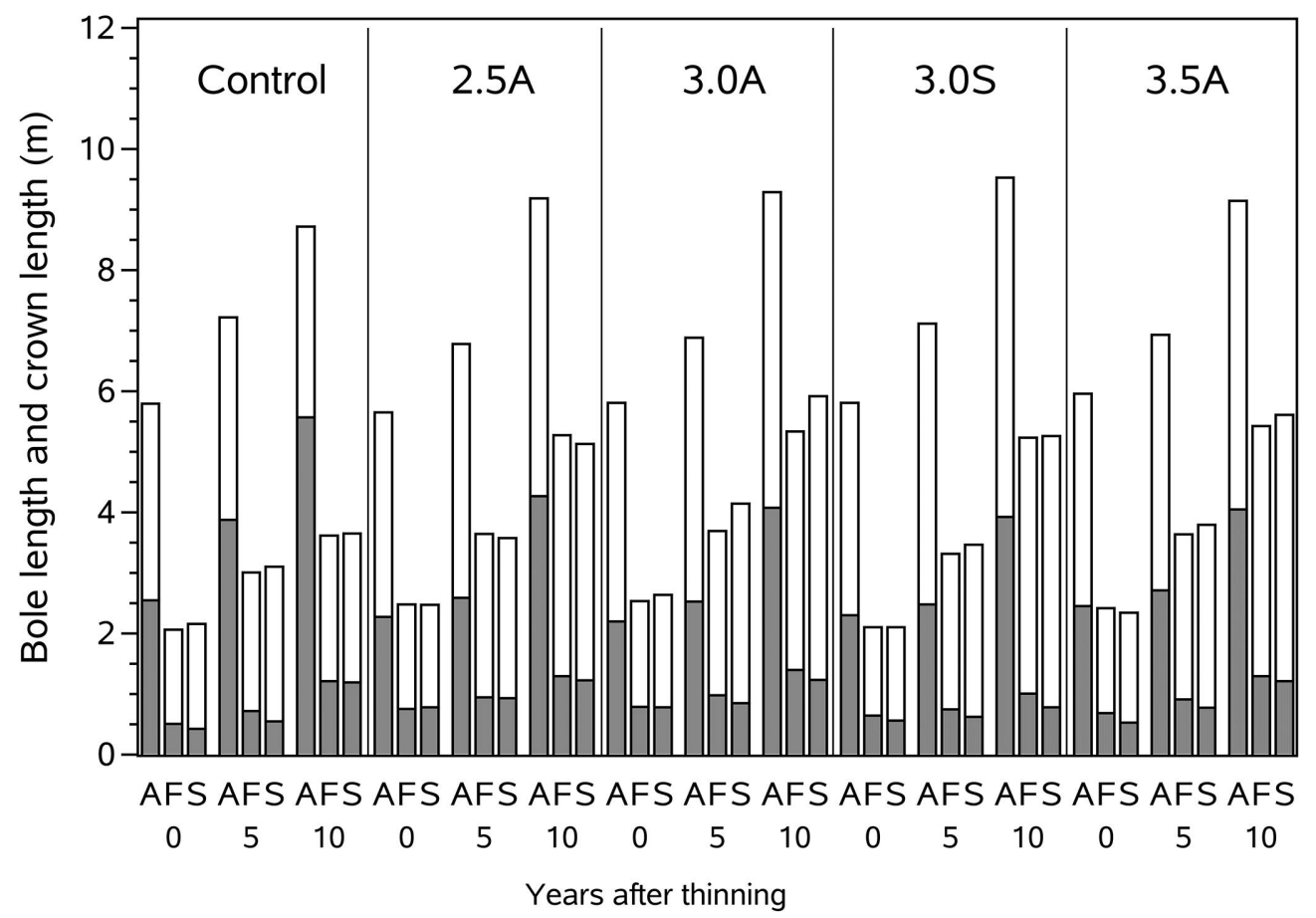

Fig. 2. Bole length (grey bar) and live crown length (empty bar) of trembling aspen (A), balsam fir (F) and spruce (S) related to PCT treatment: unthinned control, 2.5-, 3.0- and 3.5-m aspen spacings protecting all understory conifers (respectively 2.5A, 3.0A and 3.5A), and a 3.0-m spacing protecting only small understory conifers (3.0S), at years 0,5 and 10 post-thinning

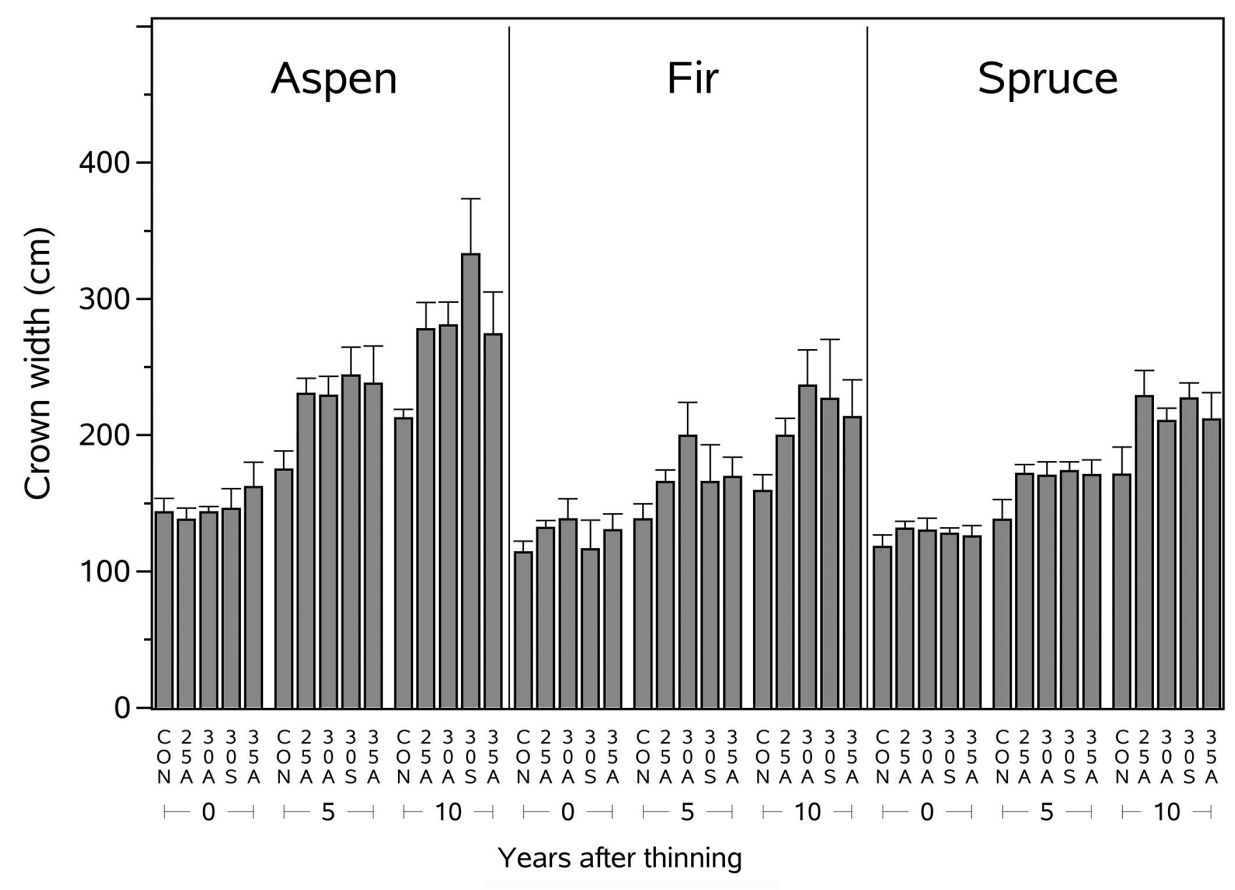

Fig. 3. Live crown width of trembling aspen, balsam fir and spruce related to PCT treatment: unthinned control (CON), 2.5-, 3.0- and 3.5-m aspen spacings protecting all understory conifers (respectively 25A, 30A and 35A), and a 3.0-m spacing protecting only small understory conifers (30S), at years 0, 5 and 10 post-thinning. Error bars represent standard error of treatment means ( $\mathrm{n}=4$ ) 
Table 2. Analysis of variance and associated probabilities $(P>F$ with repeated measurements $[1,2,3,5,7$ and 10 years postthinning) of regeneration density (stems/ha, $>30 \mathrm{~cm}$ in height] related to species and PCT treatment: unthinned control, 2.5-, 3.0- and 3.5-m aspen spacings protecting all understory conifers, and a 3.0-m spacing protecting only small understory conifers $[<1 / 3$ of the retained aspen height).

\begin{tabular}{lcccccccccc}
\hline $\begin{array}{l}\text { Source of } \\
\text { variation }\end{array}$ & df & $\begin{array}{c}\text { Trembling } \\
\text { aspen }\end{array}$ & $\begin{array}{c}\text { Paper } \\
\text { birch }\end{array}$ & $\begin{array}{c}\text { Red } \\
\text { maple }\end{array}$ & Spruce & $\begin{array}{c}\text { Balsam } \\
\text { fir }\end{array}$ & $\begin{array}{c}\text { Mountain } \\
\text { maple }\end{array}$ & $\begin{array}{c}\text { Striped } \\
\text { maple }\end{array}$ & $\begin{array}{c}\text { Beaked } \\
\text { hazelnut }\end{array}$ & $\begin{array}{c}\text { Pin } \\
\text { cherry }\end{array}$ \\
\hline PCT & 4 & 0.203 & 0.198 & $<\mathbf{0 . 0 0 1}$ & 0.910 & $\mathbf{0 . 0 4 0}$ & 0.425 & 0.639 & $\mathbf{0 . 0 3 7}$ & $\mathbf{0 . 0 1 3}$ \\
Time $(\mathrm{T})$ & 5 & $<\mathbf{0 . 0 0 1}$ & $<\mathbf{0 . 0 0 1}$ & $<\mathbf{0 . 0 0 1}$ & 0.323 & $<\mathbf{0 . 0 0 1}$ & $<\mathbf{0 . 0 0 1}$ & $<\mathbf{0 . 0 0 1}$ & $\mathbf{0 . 0 0 6}$ & $<\mathbf{0 . 0 0 1}$ \\
PCT $\times$ T & 20 & $<\mathbf{0 . 0 0 1}$ & $\mathbf{0 . 0 4 1}$ & 0.427 & 0.996 & 0.576 & 0.607 & 0.266 & 0.203 & 0.617 \\
Covariate & 1 & - & - & $<\mathbf{0 . 0 0 1}$ & - & $<\mathbf{0 . 0 0 1}$ & - & $<\mathbf{0 . 0 0 1}$ & $\mathbf{0 . 0 2 0}$ & - \\
\hline
\end{tabular}

Note: Data were transformed for all species $(\sqrt{ } \mathrm{x})$. The variance-covariance matrix was spatial power for all species. $d f=$ degrees of freedom of the numerator. Denominator degrees of freedom, according to Kenward-Roger: $\mathrm{PCT}=12.5$ to $15.3, \mathrm{~T}=58.5$ to $75.0, \mathrm{PCT} \times \mathrm{T}=59.5$ to 74.9 . Significant $p$-values are presented in boldface type. A dash indicates that the covariate was not significant and was removed from the model.

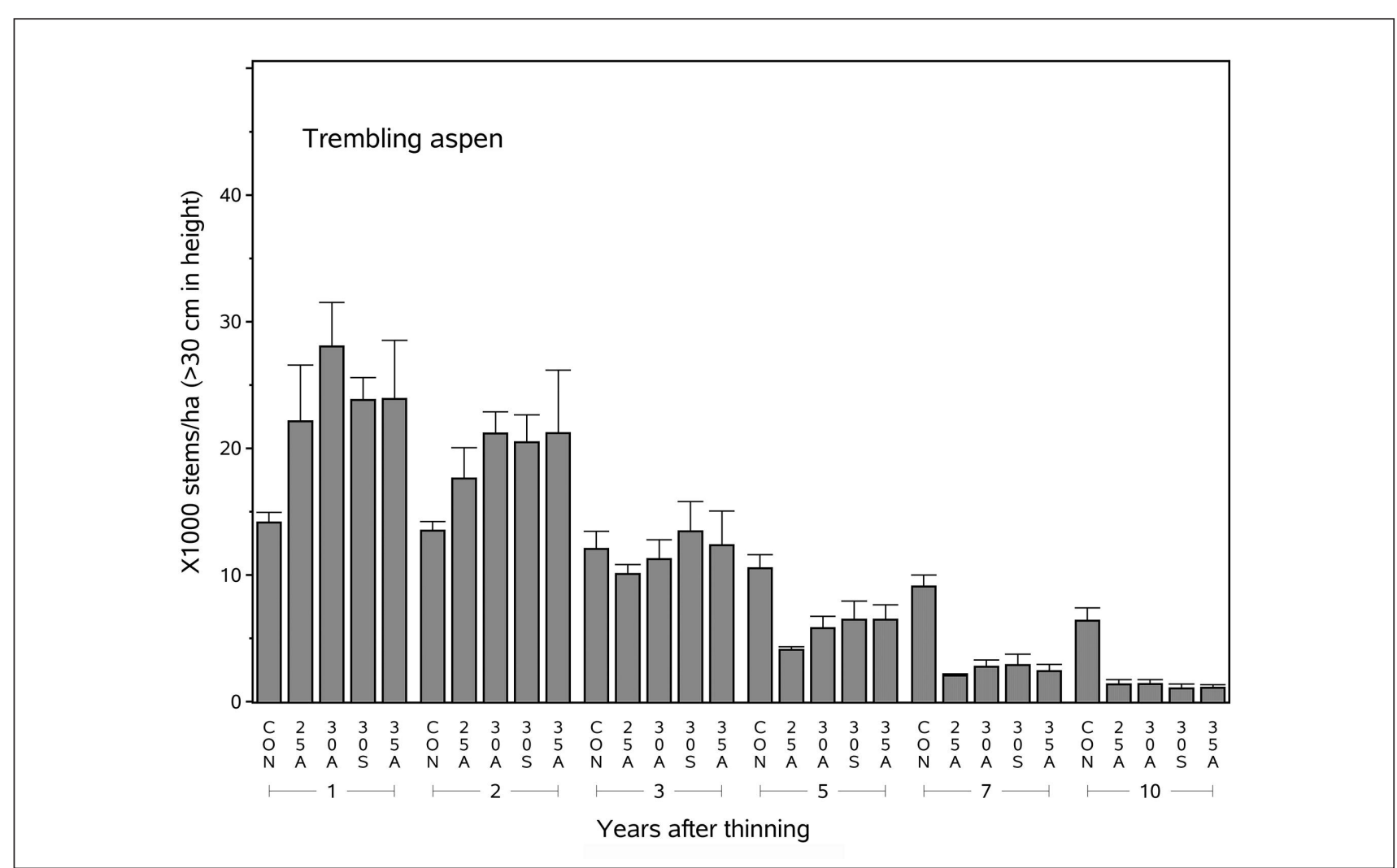

Fig. 4. Density of trembling aspen regeneration (stems/ha, $>30 \mathrm{~cm}$ in height) related to PCT treatment: unthinned control (CON), 2.5-, 3.0- and 3.5-m aspen spacings protecting all understory conifers (respectively 25A, 30A and 35A), and a 3.0-m spacing protecting only small understory conifers (30S), at years 1-3, 5, 7 and 10 post-thinning. Error bars represent standard error of treatment means $(n=4)$

$3.0 \mathrm{~A}(123 \mathrm{~cm})$ treatment. PCT did not clearly influence bole length of aspen and fir, despite the significant PCT $\times$ T interaction for aspen.

A PCT effect was found in crown width of balsam fir ( $p=0.001$, Table 1; Fig. 3), while an effect of time was also detected in crown width and bole length of this species (both $p<0.001$; Fig. 2). For the 10-year period, fir had wider crowns in treatments $2.5 \mathrm{~A}, 3.0 \mathrm{~A}$ and $3.5 \mathrm{~A}(169-177 \mathrm{~cm})$, and $3.0 \mathrm{~S}$ $(176 \mathrm{~cm})$ than in the CON $(142 \mathrm{~cm}$, both $p=0.001)$. The time effect was linear for these variables, and for crown width of fir, this resulted in a mean decennial gain of $8 \mathrm{~cm} /$ year.

\section{Regeneration dynamics}

A PCT $\times \mathrm{T}$ interaction was found for density of trembling aspen and paper birch $>30 \mathrm{~cm}$ in height $(p \leq 0.041$, Table 2; Fig. 4). At year 1 post-thinning, aspen density was lower in the CON (14 100 stems/ha) than in all PCT treatments (22 100-28 000 stems/ha, $p \leq 0.006$ ). Conversely, density in the CON (10 500 stems/ha) was higher than in treatments 2.5A, 3.0A and 3.5A (4100-6500 stems/ha, $p=0.001)$ at year 5 , and higher (6400 stems/ha) than in all PCT treatments (1100-1400 stems/ha, both $p<0.001$ ) at year 10 . The time effect indicated that significant aspen mortality mainly 


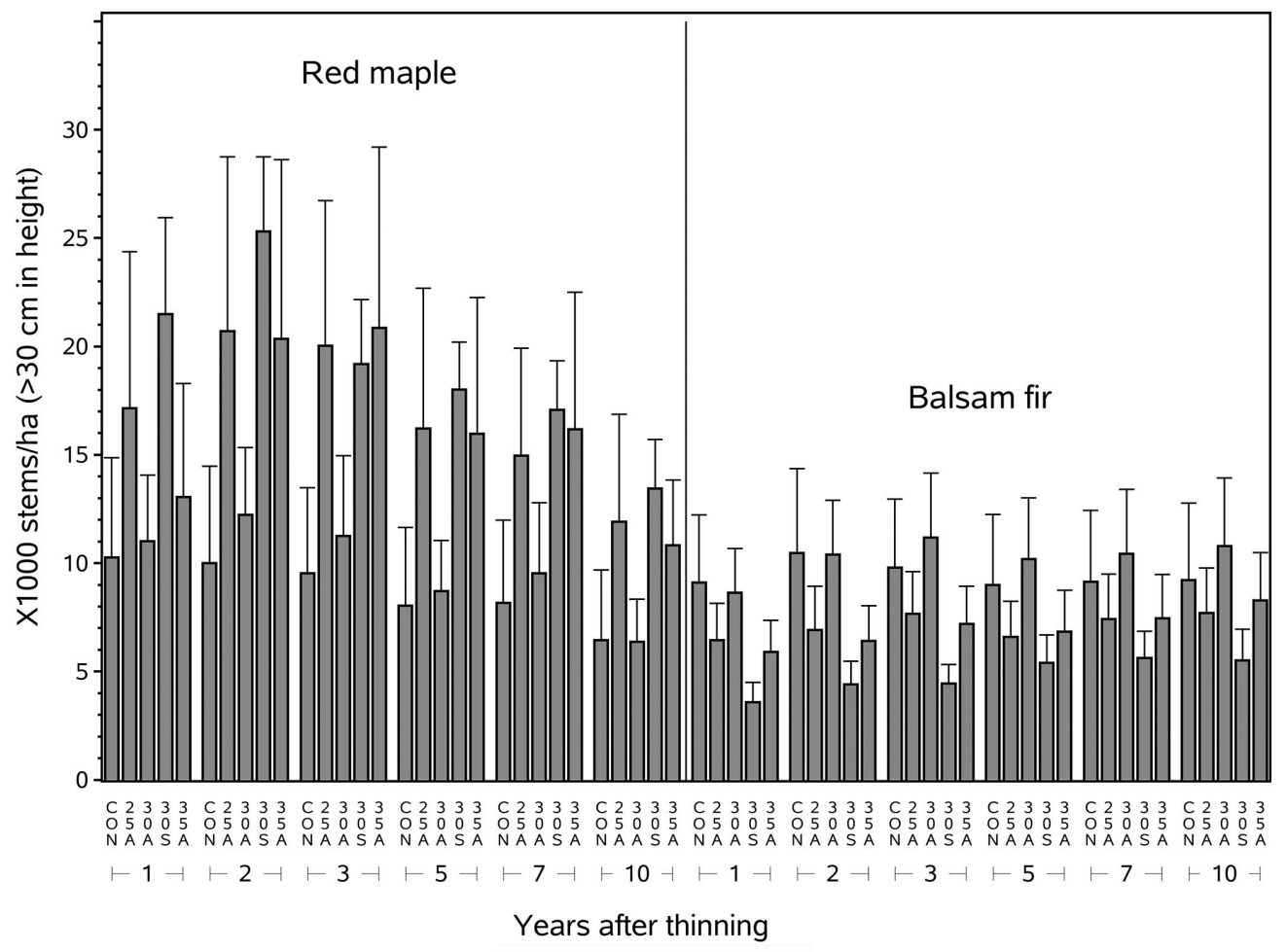

Fig. 5. Density of red maple and balsam fir regeneration (stems/ha, $>30 \mathrm{~cm}$ in height) related to PCT treatment: unthinned control (CON), 2.5-, 3.0- and 3.5-m aspen spacings protecting all understory conifers (respectively 25A, 30A and 35A), and a 3.0-m spacing protecting only small understory conifers (30S), at years 1-3, 5, 7 and 10 post-thinning. Error bars represent standard error of treatment means $(n=4)$

occurred in years $1-5$ in treated units (all $p<0.001)$ and in years $5-10$ in the CON. Despite the PCT $\times$ T interaction that was found for paper birch density, contrasts of interest within the PCT treatments were not significant.

PCT affected regeneration density $(>30 \mathrm{~cm}$ in height) of red maple, balsam fir, beaked hazelnut and pin cherry ( $p \leq 0.040$, Table 2; Figs. 5 and 6). Over the 10-year period, more red maple was found in the $2.5 \mathrm{~A}, 3.0 \mathrm{~A}$ and $3.5 \mathrm{~A}$ (9900-16 800 stems/ha, $p=0.001$ ), and 3.0S (19 100 stems/ha, $p<0.001)$ than in the CON (8700 stems/ha). The 3.0S also contained less balsam fir (4800 vs. 9500 stems/ha, $p=0.030$ ) and more hazelnut (12 500 vs. 2800 stems/ha, $p=0.049$ ) than the CON. The 3.5A tended to contain more pin cherry than the $2.5 \mathrm{~A}$ ( 2100 vs. 600 stems/ha, $p=0.062$ ). Finally, time effect was significant for the density of red maple, balsam fir, mountain maple, stripe maple, beaked hazelnut and pin cherry ( $p \leq 0.006$, Table 2 ). Significant recruitment was detected in years 1-2 for all species, except pin cherry. Thereafter, decreases in density were observed for red maple (years $3-5,7-10$ ), mountain maple (years $2-3,3-5$ ), striped maple (years 7-10) and pin cherry (years 2-3), while balsam fir and beaked hazelnut density did not significantly change over time. Year 10 density was 9800, 8300, 4300, 2700, 6600 and 200 stems/ha, respectively, for red maple, fir, mountain maple, striped maple, hazelnut and cherry. PCT and time did not affect the density of spruce regeneration.

\section{Discussion}

\section{Mortality and browsing}

Over the 10-year period of this study, half of the aspen stems died standing in the control. This is consistent with high natural mortality that has been observed in young aspen stands (e.g., Bokalo et al. 2007) and exemplifies the self-thinning ability of this pioneer species (Perala 1990). Our results indicate that PCT lowered aspen mortality, while greatly improving spruce survival. Indeed, decennial spruce mortality was high in the control (24\%) relative to PCT treatments (0-4\%), indicating that aspen self-thinning was not sufficient to sustain an adequate understory light environment for white spruce (Nienstaedt and Zasada 1990) and black spruce (Viereck and Johnston 1990), which are less shade-tolerant than balsam fir. Height growth of balsam fir has already been related to available solar radiation in a comparable PCT experiment (Prévost and Gauthier 2012). In the present study, increased light availability not only improved growth of both conifers (Fig. 1), but also critically enhanced spruce survival. This suggests that PCT may be used to enhance the spruce component at an early stage of development in boreal mixedwood stands where spruce is more desirable than balsam fir, given its better wood properties and resistance to spruce budworm (Choristoneura fumiferana Clem.).

It is not totally unclear how PCT affected browsing. Our experimental units were relatively small and did not allow a 


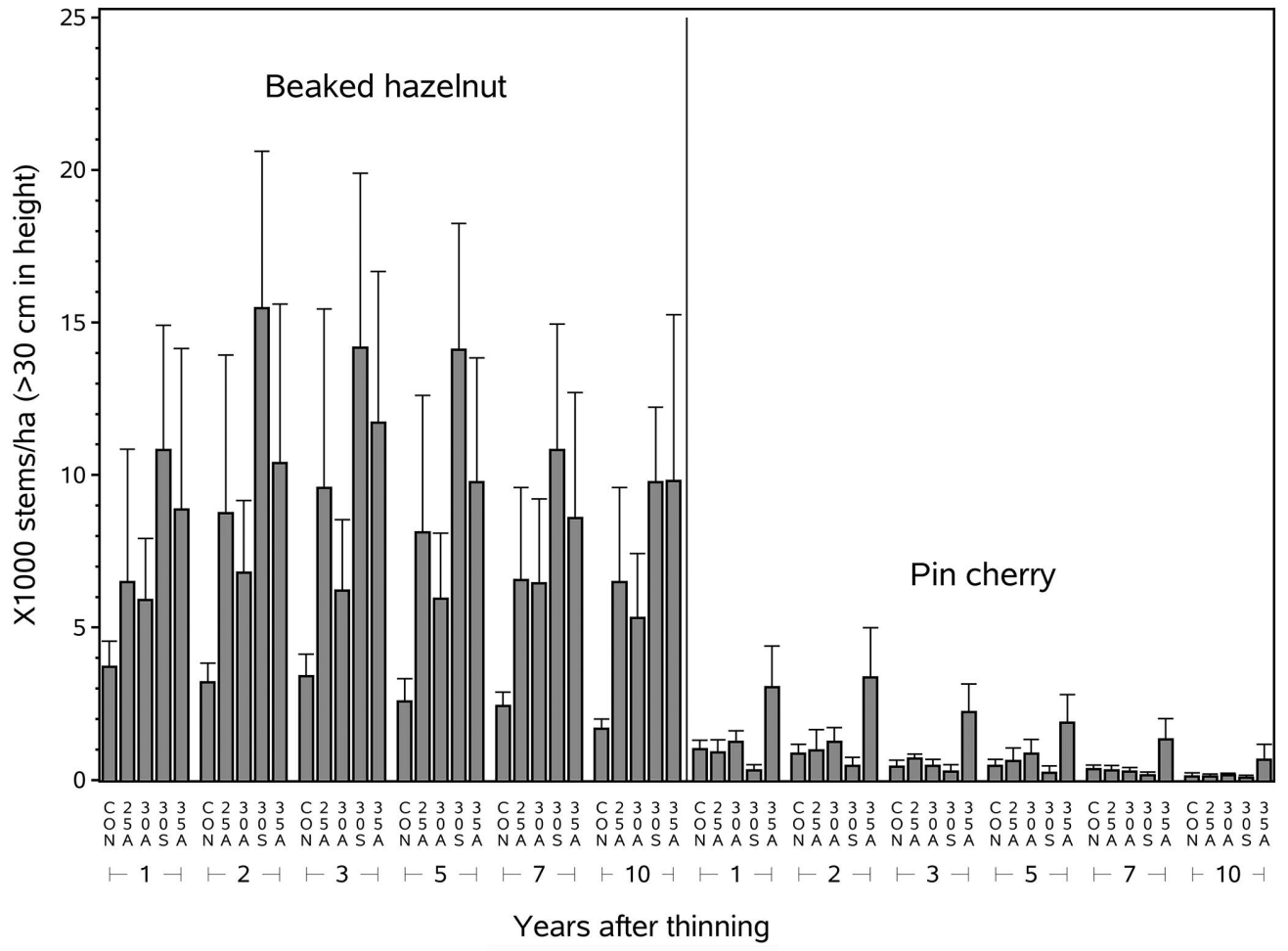

Fig. 6. Density of beaked hazelnut and pin cherry regeneration (stems/ha, $>30 \mathrm{~cm}$ in height) related to PCT treatment: unthinned control (CON), 2.5-, 3.0- and 3.5-m aspen spacings protecting all understory conifers (respectively 25A, 30A and 35A), and a 3.0-m spacing protecting only small understory conifers (30S), at years 1-3, 5, 7 and 10 post-thinning. Error bars represent standard error of treatment means $(n=4)$

clear interpretation of herbivore movement behaviour (e.g., Leblond et al. 2010). In addition, the occurrence of browsing was noted without identification of damage types. Nevertheless, the data seem to indicate that thinning with removal of the tallest coniferous regeneration increased browsing on aspen. The scarcity and low height of conifers in the 3.0S treatment likely increased selection of aspen crop trees. Also, we noted that tree spacing seemed to facilitate moose finescale movements in treated units. For instance, frequent bark stripping was observed on aspen without being detected as a significant treatment effect. The exact reason why browsing on fir appeared to be limited following thinning with retention of tall conifers is not known. The proportion of fir that was affected in these treatments $(2.5 \mathrm{~A}, 3.0 \mathrm{~A}$ and $3.5 \mathrm{~A})$ was four-fold lower than in the control. Retention of tall conifers may have provided more choice of food for moose in thinned units. Among other explanations, we hypothesize that the unthinned control may have been preferentially occupied by moose for its sheltered conditions (Schwab and Pitt 1991) and by snowshoe hare for its dense shrubby vegetation (Litvatis et al. 1985). Further observations are required to gain greater insight into browsing with regard to conifer retention, as it certainly influences availability and choice of food.

\section{Growth}

Thinning was applied to the aspen but the treatment enhanced $\mathrm{DBH}$ growth of both aspen and understory conifers (Fig. 1). Contrary to our first and second hypotheses, however, this effect was not proportional to aspen spacing after 10 years. The DBH growth increase averaged $90 \%$ for aspen which is higher than the 10 -year gains of $55 \%$ and $61 \%$ observed in Ontario aspen stands that were thinned respectively at 10- and 15-year-old (Rice et al. 2001). Although the response was detected later on conifers, their $\mathrm{DBH}$ increment and height growth doubled without affecting aspen $\mathrm{DBH}$ response, thereby confirming our third hypothesis. The height growth response of conifers was only detected after 10 years; such a delay could explain why Bokalo et al. (2007) found no effect of aspen spacing on white spruce height after 3-4 years in western Canada. Furthermore, the 100\% decennial gain was lower than the $200-300 \%$ gains that were reported for understory balsam fir in the Saguenay-LacSaint-Jean region of Quebec (Prévost and Gauthier 2012). Nevertheless, this study supports the use of PCT to allow conifer ingress into openings, as has been suggested by Rice et al. (2001). Both spruce and fir responded well to this form of release cutting. This rejects our fourth hypothesis predicting a better response of fir than spruce, which is yet another positive outcome from a silvicultural perspective. The growth curves also indicate that both species responded well in the treatment that retained only small regeneration (3.0S; Fig. 1); this response is consistent with the ability of young conifers to respond to release (Ruel et al. 2000). As a whole, we conclude that thinning accelerated early development of the stratified 
species mixture (Smith et al. 1997), thereby enhancing growth of both aspen and conifers through the implementation of an ecosystem-based silvicultural approach.

Crown development of all species was enhanced by PCT. As was the case for $\mathrm{DBH}$, aspen response occurred earlier and was less pronounced than conifer response. Moreover, live crown characteristics illustrate the stratification that had been developing in thinned and control experimental units (Fig. 2). At both years 5 and 10, aspen and conifer crowns had an optimal vertical arrangement in the canopy space of thinned units. The treatment allowed the sharing of growing space in an intimate species mixture where the spatial complementarity in tree crowns enhanced light interception and use (Williams et al. 2017). At year 10, shorter conifer crowns in the control were indicative of overtopping, which may develop into a mature aspen-dominated stand with suppressed advance growth (e.g., MacDonald et al. 2004). Such stands represent an even greater challenge for maintaining coniferous species (Greene et al. 2002) for instance, which may require careful application of two-step shelterwood cutting (Prévost and DeBlois 2014). In the present study, we intervened at the early stage of stand development by spacing aspen saplings and taking particular care with understory conifers. Future surveys would indicate how this approach using spatial complementarity of species could influence structural stand development and further silvicultural interventions.

Thinning resulted in $80-90 \%$ immediate lowering of aspen BA (year 0), but the growth potential of residual selected crop trees should be enhanced from greater growing space on individual tree basis (Smith et al. 1997). Furthermore, the residual aspen BA of $1-2 \mathrm{~m}^{2} /$ ha was below the levels that were suggested by Comeau (2001) to provide nearoptimal understory conditions for white spruce growth $\left(<8 \mathrm{~m}^{2} / \mathrm{ha}\right)$ or survival $\left(<20 \mathrm{~m}^{2} / \mathrm{ha}\right)$. The residual BA of balsam fir was adversely affected by the two different measures of advanced growth protection in the $3.0-\mathrm{m}$ spacing, with an $80 \%$ immediate loss following the operational approach (treatment 3.0S: $<1 / 3$ of the aspen crop tree height). This may indicate the extent to which retention of taller stems can enhance conifer site occupancy in the short-term, although the growth response of young firs has decreased the net BA loss to $65 \%$ in 10 years. Because aspen occupies the main canopy, we believe that its growth response will remain independent of understory conifers, as long as the latter remain in a lower position. Monitoring aspen development in the two 3.0-m spacings with different levels of conifer retention (3.0A vs. 3.0S) would allow us to validate this assumption. Further, all treatments should ultimately be evaluated in terms of merchantable $(\mathrm{DBH} \geq 9.1 \mathrm{~cm})$ BA by species, and $\mathrm{BA}$ and volume per stem to assess sawlog potential with regard to branching (e.g., Weiskittel et al. 2009), wood density and lumber strength (Zhang et al. 2006).

\section{Regeneration}

Aspen asexual reproduction capacity was observed after thinning in the 8-year-old stand under study. Substantial suckering and stump sprouting occurred in all treated experimental units, but most aspen stems that emerged post-thinning rapidly died out (Fig. 4). From year 5 onward, treated units contained fewer stems than the control and aspen density was constantly lowered. This transient aspen regrowth was found to be independent of levels of spacing or advance growth protection. Nevertheless, the shade of residual aspen trees, retained conifers and other regenerated species certainly contributed to the quick death of new aspen suckers. It is also probable that widespread root connections had a confounding effect on post-thinning vegetative reproduction and decline (Baret and DesRochers 2011). For instance, root connections between cut trees and crop trees may restrict resources (water, nutrients and carbohydrates) for root suckers and stump sprouts (DesRochers and Lieffers 2001). This was already suspected following thinning (Prévost and Gauthier 2012); our field observations of low-vigour aspen regrowth precisely suggest that resources provided by the existing root systems were limited.

PCT retaining all advance growth was more efficient in maintaining overall conifer regeneration. Therefore, our fifth hypothesis asserting a PCT effect on conifers was confirmed only for balsam fir in the $3.0-\mathrm{m}$ spacing that retained only small advance growth (Fig. 5). We believe that fir was affected by this lowest level of retention because it far outnumbered spruce in tall conifer regeneration of the stand. Other species that occupied the understory prior to thinning regenerated in all treatments. Owing to abundant vegetative reproduction, red maple, mountain maple, striped maple and beaked hazelnut accounted for more than 20000 stems/ha after 10 years. This agrees with the regeneration dynamics observed by Prévost and Gauthier (2012) following thinning in a comparable stand. However, red maple and beaked hazelnut were the only species to experience increases in density post-thinning and removal of tallest conifers facilitated their development (Figs. 5 and 6). Given that it is capable of rapidly capturing the available growing space (Fei and Steiner 2009), red maple increased by $120 \%$ following the removal of tall conifers, compared to $60 \%$ following their retention. Beaked hazelnut also benefited from removal of the tallest conifers, with an increase of $450 \%$ with respect to the control. This treatment greatly stimulated hazelnut vegetative reproduction, but those treatments retaining tall conifers also contained two to three times more hazelnut than the control over the 10 -year period. It is likely that inherent variability of spatial distribution of this species prevented this effect from being detected statistically. Like aspen, beaked hazelnut can reproduce by both sprouting and suckering (Tappeiner 1971) which may explain the abundant recruitment of the species. In this study, red maple and beaked hazelnut quickly captured the growing space following thinning and benefited most from removal of tall conifer advance growth.

The effect of PCT on pin cherry regeneration from germination of buried seeds (Wendel 1990) needs to be interpreted cautiously. Other treatments (including the control) had mean densities of pin cherry (300-700 stems/ha) that were as low as the narrowest spacing, without being formally tested or declared statistically different from the widest spacing. A closer inspection of the data revealed that some regeneration subplots contained high numbers of pin cherry stems in one experimental unit of the $3.5-\mathrm{m}$ spacing. It is possible that this widest spacing interacted with an important seed bank that was localized in this unit, which seems to be supported by the observed greater variation in the data. 


\section{Conclusions}

Thinning in pure aspen stands is rightly under debate due to the self-thinning ability of this shade-intolerant species. However, aspen often overtops conifers in early successional boreal mixedwood stands. In such stratified mixtures, aspen self-thinning is not sufficient to create understory conditions for optimal growth and survival of conifers. Results from this study confirm that PCT may be viewed as a means of redistributing resources to fewer aspen stems in the upper canopy, while releasing understory conifers from suppression. The positive growth and survival responses of conifers must be considered when evaluating the overall merit of PCT in aspen-dominated stands. By favouring species mixtures and limiting stand hardwood conversion in the boreal mixedwood forest, this approach could be considered as an ecosystem-based forest management practice. Growing species in mixtures has been recently gaining interest, and modulating growth and composition of species mixtures that readily establish over vast areas could result in a low-cost, highreturn silvicultural practice.

\section{Acknowledgements}

We thank the Associate Editor of the journal and two anonymous reviewers for their helpful comments. William F.J. Parsons is also acknowledged for his English-language editing assistance. The authors are also indebted to Coop Quatre Temps (Valérie Laberge), Abitibi-Consolidated Inc. (Resolute Forest Products) and regional staff of the Ministère des Forêts, de la Faune et des Parcs for their excellent collaboration. Heartfelt thanks are extended to Jean-Pierre Lapointe, Maurice Gagnon, Julie Forgues, Carlo Gros-Louis, Daniel Guimond, Serge Williams, Pascal Lainé, Étienne Du Berger, Christian Villeneuve and the many summer students for their excellent fieldwork over the years. This study is part of Project 142332017 of the Direction de la recherche forestière, MFFPQ.

\section{References}

Baret, M. and A. DesRochers. 2011. Root connections can trigger physiological responses to defoliation in nondefoliated aspen suckers. Botany 89: 753-761.

Bokalo, M., P.G. Comeau and S.J. Titus. 2007. Early development of tended mixtures of aspen and spruce in western Canadian boreal forests. For. Ecol. Manage. 242: 175-184.

Braat, S., D. Gerhard and L.A. Hothorn. 2008. Joint one-sided and two-sided simultaneous confidence intervals. J. Biopharm. Stat. 18: 293-306.

Brissette, J.C., R.M., Jr Frank, T.L. Stone and T.A. Skratt. 1999. Precommercial thinning in a northern conifer stand: 18-year results. For. Chron. 75: 967-972.

Comeau, P.G. 2001. Relationships between stand parameters and understory light in boreal aspen stands. B.C. J. Ecosyst. Manage. 1: 1-8. DesRochers, A. and V.J. Lieffers. 2001. The coarse-root system of mature Populus tremuloides in declining stands in Alberta. Canada. J. Veg. Sci. 12: 355-360.

Fei, S. and K.C. Steiner. 2009. Rapid capture of growing space by red maple. Can. J. For. Res. 39: 1444-1452.

Fleming, R.L., D.S. Mossa and G.T. Marek. 2005. Upland black spruce stand development 17 years after cleaning and precommercial thinning. For. Chron. 81: 31-41.

Greene, D.F. et al. 2002. Modelling silvicultural alternatives for conifer regeneration in boreal mixedwood stands (aspen/white spruce/balsam fir). For. Chron. 78: 281-295.
Groot, A., J.-M. Lussier, A.K. Mitchell and D.A. MacIsaac. 2005. A silvicultural systems perspective on changing Canadian forestry practices. For. Chron. 81: 50-55.

Kabzems, R., M. Bokalo, D.A. MacIsaac and P.G. Comeau. 2016. Managed mixtures of aspen and white spruce 21 to 25 years after establishment. Forests 7, 5; doi:10.3390/f7010005.

Karsh, M.B., M.B. Lavigne and J.G. Donnelly. 1994. Growth responses of the balsam fir and black spruce spacing trials. Can. For. Serv. Inf. Rep. N-X-291.

Leak, W.B. and M. Yamasaki. 2012. 80 years of thinning research on northern hardwoods in the Bartlett experimental forest, New Hampshire. USDA For. Serv. Res. Pap. NRS-20.

Leblond, M., C. Dussault and J.-P. Ouellet. 2010. What drives finescale movements of large herbivores? A case study using moose. Ecography 33: 1102-1112.

Litvatis, J.A., J.A. Sherburne and J.A. Bissonette. 1985. Influence of understory characteristics on snowshoe hare habitat use and density. J. Wild. Manage. 49: 866-873.

MacDonald, G.B. 1995. The case for boreal mixedwood management: An Ontario perspective. For. Chron. 71: 725-734.

MacDonald, G.B., M.L. Cherry and D.J. Thompson. 2004. Effect of harvest intensity on development of natural regeneration and shrubs in an Ontario boreal mixedwood stand. For. Ecol. Manage. 189: 207-222.

Man, R. and V.J. Lieffers. 1999. Are mixtures of aspen and white spruce more productive than single species stands? For. Chron. 75: 505-513.

McCain, K.M., D.M. Morris, S.C. Hills and L.J. Buse. 1994. The effects of initial spacing on growth and crown development for planted northern conifers: 37-year results. For. Chron. 70: 174-182. MDDELCC. 2016. [Ministère du développement durable, de l'environnement et de la lutte contre les changements climatiques]. Normales climatiques du Québec 1981-2010. Station Petit-Saguenay [online]. Available from http://www.mddelcc.gouv.qc.ca/climat/ normales/index.asp. [accessed 11 May 2016].

Newton, P.F. and G.F. Weetman. 1994. Stand density management diagram for managed black spruce stands. For. Chron. 70: 65-74.

Nicholson, J., T. McGrath, B. Murray and T. Rushton. 2010. The long-term branching and diameter response of pre-commercially thinned hardwood stands in Nova Scotia. Nova Scotia Dep. Nat. Resour. For. Res. Rep. 90.

Nienstaedt, H. and J.C. Zasada. 1990. White spruce - Picea glauca (Moench) Voss. In: R.M. Burns and B.H. Honkala (eds.). Silvics of North America. pp. 204-226. USDA For. Serv. Agric. Handb. No. 654 , vol. 1. Conifers. Washington, DC.

Penner, M., C. Robinson and M. Woods. 2001. The response of good and poor aspen clones to thinning. For. Chron. 77: 874-884.

Perala, D.A. 1990. Quaking aspen - Populus tremuloides Michx. In: R.M. Burns and B.H. Honkala (eds.). Silvics of North America. pp. 555-569. USDA For. Serv. Agric. Handb. No. 654, vol. 2. Hardwoods. Washington, DC.

Pitt, D.G. and F.W. Bell. 2005. Juvenile response to conifer release alternatives on aspen-white spruce boreal mixedwood sites. Part 1: Stand structure and composition. For. Chron. 81: 538-547.

Pitt, D. and L. Lanteigne. 2008. Long-term outcome of precommercial thinning in northwestern New Brunswick: growth and yield of balsam fir and red spruce. Can. J. For. Res. 38: 592-610.

Pothier, D. 2002. Twenty-year results of precommercial thinning in a balsam fir stand. For. Ecol. Manage. 168: 177-186.

Pothier, D. and H. Margolis. 1991. Analysis of growth and light interception of balsam fir and white birch saplings following precommercial thinning. Ann. Sci. For. 48: 123-132.

Prévost, M. and M.-M. Gauthier. 2012. Precommercial thinning increases growth of overstory aspen and understory balsam fir in a boreal mixedwood stand. For. Ecol. Manage. 278: 17-26.

Prévost, M. and J. DeBlois. 2014. Shelterwood cutting to release conifer advance growth and limit aspen sucker development in a boreal mixedwood stand. For. Ecol. Manage. 323: 148-157. 
Prévost, M., D. Dumais and J. DeBlois. 2016. Morphological response of conifer advance growth to canopy opening in mixedwood stands, in Quebec, Canada. Trees 30: 1735-1747.

Rice, J.A., G.B. MacDonald and D.H. Weingartner. 2001. Precommercial thinning of trembling aspen in northern Ontario: Part 1 Growth responses. For. Chron. 77: 893-901.

Ruel, J.-C., C. Messier, R. Doucet, Y. Claveau and P. Comeau. 2000. Morphological indicators of growth response of coniferous advance regeneration to overstorey removal in the boreal forest. For. Chron. 76: 633-642.

Saucier, J.-P. et al. 2009. Écologie forestière. In: Ordre des ingénieurs forestiers du Québec (ed.). Manuel de foresterie, 2e éd. pp. 165-315. Ouvrage collectif, Éditions Multimondes, Québec, QC.

Schwab, F.E. and M.D. Pitt. 1991. Moose selection of canopy cover types related to operative temperature, forage, and snow depth. Can. J. Zool. 69: 3071-3077.

Smith, D.M., B.C. Larson, M.J. Kelty and P.M.S. Ashton. 1997. The Practice of Silviculture: Applied Forest Ecology. Ninth Edition. John Wiley \& Sons Inc. New York, NY.

Sterba, H. 1988. Increment losses by full-tree harvesting in Norway spruce (Picea abies). For. Ecol. Manage. 24: 283-292.

Su, Q., T.D. Needham and D.A. MacLean. 1996. The influence of hardwood content on balsam fir defoliation by spruce budworm. Can. J. For. Res. 26: 1620-1628.

Swift, D.E., W. Knight, M. Béland, I. Boureima, C.P.-A. Bourque and F.-R. Meng. 2017. Stand dynamics and tree quality response to precommercial thinning in a northern hardwood forest of the Acadian forest region: 23 years of intermediate results. Scan. J. For. Res. 32: 45-59.

Tappeiner, J.C. 1971. Invasion and development of beaked hazel in red pine stands in northern Minnesota. Ecol. 52: 514-519.

Thibodeau, L., P. Raymond, C. Camiré and A.D. Munson. 2000. Impact of precommercial thinning in balsam fir stands on soil nitrogen dynamics, microbial, biomass, decomposition, and foliar nutrition. Can. J. For. Res. 30: 229-238.
Van Cleve, K., L. Oliver, R. Schlentner, L.A. Viereck and C.T. Dyrness. 1983. Productivity and nutrient cycling in taiga forest ecosystems. Can. J. For. Res. 13: 747-766.

Viereck, L.A. and W.F. Johnston. 1990. Black spruce - Picea mariana (Mill.) BSP. In: R.M. Burns and B.H. Honkala (eds.). Silvics of North America. pp. 227-237. USDA For. Serv. Agric. Handb. No. 654 , vol. 1. Conifers. Washington, DC.

Voorhis, N.G. 1990. Precommercial crop-tree thinning in a mixed northern hardwood stand. USDA For. Serv. Res. Pap. NE-640.

Weiskittel, A.R., L.S. Kenefic, R.S. Seymour and L.M. Phillips. 2009. Long-term effects of precommercial thinning on the stem dimensions, form and branch characteristics of red spruce and balsam fir crop trees in Maine, USA. Silva Fenn. 43: 397-409.

Wendel, G.W. 1990. Pin cherry - Prunus pensylvanica L. f. In: R.M. Burns and B.H. Honkala (eds.). Silvics of North America. pp. 587-593. USDA For. Serv. Agric. Handb. No. 654, vol. 2. Hardwoods. Washington, DC.

Westfall, P.H., R.D. Tobias and R.D. Wolfinger. 2011. Multiple comparisons and multiple tests using $\mathrm{SAS}^{\circledast}$. Second edition. SAS Institute Inc., Cary, NC.

Williams, L.J., A. Paquette, J. Cavender-Bares, C. Messier and P.B. Reich. 2017. Spatial complementarity in tree crowns explains overyielding in species mixtures. Nat. Ecol. Evol. 1, 0063; doi:10.1038/s41559-016-0063.

Zhang, S., G. Chauret and Q. Tong. 2009. Impact of precommercial thinning on tree growth, lumber recovery and lumber quality in Abies balsamea. Scan. J. For. Res. 24: 425-433.

Zhang, S.Y., G. Chauret, D.E. Swift and I. Duchesne. 2006. Effects of precommercial thinning on tree growth and lumber quality in a jack pine stand in New Brunswick, Canada. Can. J. For. Res. 36: 945-952. 